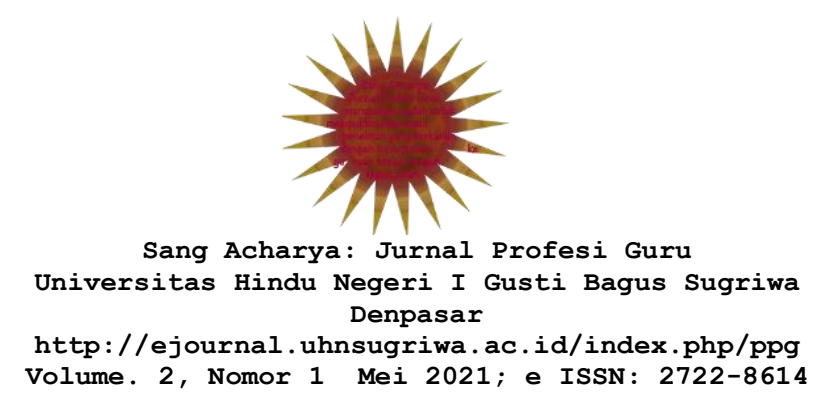

\title{
PERMAINAN TRADISIONAL BALI PENYU MATALUH SEBAGAI MEDIA PEMBELAJARAN DAN PEMBENTUKAN KARAKTER ANAK BERBASIS KEARIFAN LOKAL
}

\author{
I Wayan Nuryana ${ }^{1}$, Ni Wayan Marti Megasari ${ }^{2}$, I Wayan Mandra \\ Universitas Hindu Negeri I Gusti Bagus Sugriwa Denpasar \\ wayannuryana@gmail.com ${ }^{1}$, megasari0303090@gmail.com ${ }^{2}$, \\ wayanmandra@gmail.com
}

Diterima 3 Maret 2021, direvisi 29 April 2021, diterbitkan 1 Mei 2021

\begin{abstract}
Abstrak
Nilai-nilai karakter dapat terwujud atau tercermin dalam berbagai aspek kehidupan masyarakat, baik dalam bentuk yang abstrak maupun dalam wujud yang nyata. Sebagai contoh, nilai-nilai itu akan tampak dalam bentuk kelembagaan organisasi sosial kemasyarakatan, desa, lembaga pendidikan serta organisasi sosial lainnya, juga dapat muncul dalam bentuk permainan anak-anak. Terdapat banyak bentuk permainan anakanak dalam masyarakat Indonesia, baik dalam bentuknya yang tradisional maupun yang modern. Permainan Tradisional Bali Penyu Mataluh merupakan suatu permainan yang mengutamakan

kebersamaan dan kekompakan serta mengandung nilai-nilai pendidikan yang luhur. Sebagai salah satu hasil budaya masyarakat Bali yang telah diturunkan secara bergenerasi, permainan ini merupakan salah satu media pembelajaran yang menumbuhkan nilai, sikap, kecerdasan, solidaritas sosial, maupun karakter berlandaskan budaya pada anak-anak. Permainan ini akan berimplikasi pada terbentuknya karakter pada masa depan anak yang mencakup terbentuknya jiwa sosial kemasyarakatan berlandaskan solidaritas dan menjadi insan yang berpendidikan dengan berlandaskan budaya.
\end{abstract}

Kata Kunci : Permainan Tradisional Bali, Penyu Mataluh, Pembentukan Karakter Anak

\section{PENDAHULUAN}

Telah diketahui bahwa bangsa Indonesia merupakan kumpulan dari berbagai suku bangsa yang mendiami gugusan pulau dan memiliki tradisi, bahasa, sistem pengetahuan, kepercayaan serta karakter. Sebagai bangsa yang majemuk dan merdeka, bangsa ini baru mulai menata kehidupan berbangsa sejak tahun 1945, setelah lepas dari masa penjajahan. Tahun itu dapat disebut sebagai hari lahir Indonesia sebagai bangsa yang berdaulat, sederajat dengan bangsa-bangsa lainnya di dunia. Pada tanggal 17 Agustus 1945, dengan diproklamasikannya kemerdekaan Indonesia ke seluruh dunia oleh Soekarno-Hatta dan ditetapkannya Undang-Undang Dasar tanggal 18 Agustus 1945, bangsa Indonesia telah memiliki perangkat yang dipandang lengkap sebagai bangsa merdeka. Di dalam Pembukaan Undang-Undang Dasar dicantumkan dasar-dasar negara Indonesia Merdeka yang diangkat dari lima butir nilai Pancasila. 


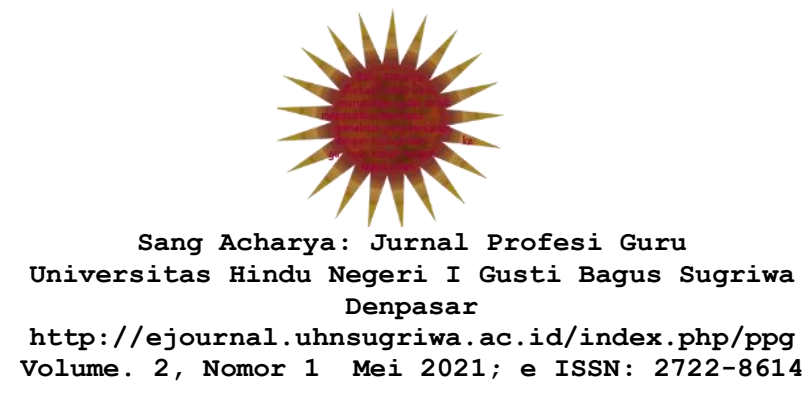

Oleh pencetusnya, lima dasar nilai itu telah digali dari dalam bumi pertiwi Indonesia, dari nilai-nilai yang terpendam, tersimpan dalam lubuk hati masyarakat Indonesia. Kelima dasar nilai tersebut dapat dipahami sebagai nilai-nilai kearifan bangsa, karakter bangsa Indonesia secara keseluruhan. Nilai-nilai itu dapat dilihat dari perilaku dalam kehidupan masyarakat Indonesia yang plural, baik pada tingkat pergaulan anakanak maupun tingkat kehidupan oramg dewasa. Atas dasar itu, masyarakat yang majemuk ini dapat dipersatukan, merasa bersama-sama memiliki nilai-nilai, landasan, pandangan hidup yang sama seperti tertuang dalam Pembukaan Undang-Undang Dasar 1945. Guna membangun rasa kebangsaan yang kokoh, pentingnya menggali nilai-nilai karakter bangsa itu dari dalam kehidupan masyarakat, selanjutnya diperkenalkan, untuk dapat menjadi pedoman bersama dalam rangka persatuan dan kesatuan bangsa, menuju pembangunan masyarkat yang adil dan makmur.

Pada era global, bangsa Indonesia sedang mengalami kerapuhan karakter, kerapuhan identitas dan krisis kepercayaan yang disebabkan oleh adanya era globalisasi. Hal ini diindikasikan oleh munculnya berbagai bentuk tindak kekerasan, korupsi, disintegrasi, degradasi moral, krisis kepercayaan dan lain-lain. Perkembangan lingkungan sosial-ekonomi dan teknologi, tuntutan ekonomi dan beban hidup keluarga yang semakin tinggi, membawa berbagai implikasi dalam kehidupan keluarga. Salah satu diantaranya adalah semakin kecilnya waktu orang tua bersama anak-anak, baik dari kualitas maupun intensitasnya. Di lain pihak, anak-anak juga "terperangkap" ke dalam pergaulan yang "baru", yang tidak selamanya sejalan dengan berbagai nilai tradisional dalam masyarakat di mana mereka berada. Di balik aspek positif yang ada, revolusi informasi dengan teknologi internet dan komputer dapat menjadi salah satu faktor yang semakin menjauhkan generasi muda dari nilai-nilai tradisional. Seringkali informasi yang dikonsumsi anak-anak mengandung unsur negatif yang secara tidak sadar berpengaruh terhadap sikap dan perilaku mereka. Permasalahan yang dihadapi generasi muda tidak terlepas dari pendidikan sejak masa anak-anak. Keluarga, sekolah dan lingkungan sekitar sangat menentukan perkembangan kepribadian anak-anak. Mereka akan lebih banyak belajar dari contoh-contoh perilaku yang diamati. Oleh karena itu, membangun karakter anak-anak harus dilakukan sejak dini dengan lebih banyak memberikan suri teladan dan tindakan-tindakan nyata.

Nilai-nilai karakter dapat terwujud atau tercermin dalam berbagai aspek kehidupan masyarakat, baik dalam bentuk yang abstrak maupun dalam wujud yang nyata. Sebagai contoh, nilai-nilai itu akan tampak dalam bentuk kelembagaan organisasi sosial kemasyarakatan, desa, lembaga pendidikan serta organisasi sosial lainnya, juga dapat muncul dalam bentuk permainan anak-anak. Terdapat banyak bentuk permainan anakanak dalam masyarakat Indonesia, baik dalam bentuknya yang tradisional maupun yang modern. Bruvand dan Dundes (dalam Endraswara, 2009) menyebutkan permainan rakyat (folk games) merupakan jenis foklor adat kebiasaan (customary folklore). Tetapi yang jelas bahwa semua permainan rakyat daerah mempunyai nilai sosialisasi yang tinggi. Karena minimal permainan itu dapat mendidik anak-anak untuk menjadi anggota masyarakat, guna bisa bergaul dengan sesamanya. Bahkan tidak jarang permainan rakyat itu dapat menanamkan rasa kejujuran, sportif dan tenggang rasa yang tinggi. Di sinilah letak perbedaan hakiki antara permainan rakyat (tradisional) dengan permainan modern 


\section{$\frac{M}{3} \frac{1}{11}$ \\ Sang Acharya: Jurnal Profesi Guru \\ Universitas Hindu Negeri I Gusti Bagus Sugriwa \\ Denpasar \\ http://ejournal. uhnsugriwa.ac.id/index.php/ppg \\ Volume. 2, Nomor 1 Mei 2021; e ISSN: 2722-8614}

yang memerlukan wasit/juri sebagai pengawas supaya permainan dapat berjalan dengan baik. Selain itu, Taro (1999) juga mengatakan bahwa permainan tradisional adalah aktifitas budaya dalam bentuk permainan dengan unsur-unsur geak, seni, sosial dan budaya. Sebagi aktivitas budaya, permainan tradisional memperkukuh nilai-nilai budaya yang dapat merangsang ke arah pembaharuanyang kreatif. Permainan tradisional adalah permainan yang diciptakan bersama-sama dan juga diwariskan secara bersama-sama (Suarka, 2011 : 3). Jika demikian halnya, dapat dikatakan bahwa permainan tradisional merupakan representasi keinginan suatu kelompok beradab yang di dalamnya terkandung kekayaan tradisi dan nilai-nilai luhuryang dijiwai oleh semangat kebesamaan.

Aktivitas bermain merupakan aktivitas yang umum dilakukan anak-anak yang sedang dalam masa tumbuh kembang. Para pakar pendidikan menyatakan bahwa dunia anak adalah dunia bermain. Bermain terungkap dalam berbagai bentuk apabila anak-anak sedang beraktivitas. Mereka bermain ketika bernyanyi, menggali tanah, membangun balok berwarna-warni, atau menirukan sesuatu yang dilihat (Montolulu, 2005 : 68). Sujiono (2005:1) menyatakan bahwa semakin kuat dan terampilnya seorang anak, membuat anak senang bermain, yang mempunyai banyak manfaat untuk pertumbuhan dan perkembangan aspek aspek kemampuan anak seperti aspek perkembangan kognitif dan aspek perkembangan sosial

emosional anak. Permainan tradisional Bali merupakan salah satu bentuk hasil budaya yang menjadi media pembelajaran bagi anak-anak, khususnya di Bali. Ada beragam permainan tradisional Bali, salah satunya adalah permainan tradisional "penyu mataluh", yang merupakan permainan tradisional yang dimainkan oleh anak-anak di daerah pantai pada sat bulan purnama. Permainan ini dimainkan oleh sekelompok anak-anak yang bermain sambil menyanyikan lagu berjudul "Bulan Makalangan" yang berbahasa Bali dan pada puncaknya terjadi saling kejar mengejar antara kelompok anak yang berperan sebagai nelayan dengan kelompok anak yang berperan sebagai penyu yang meindungi telurnya. Dalam permainan ini dituntut kekompakan dan kerjasama yang solid antar-anak. Masa bermain sangat penting bagi pembentukan karakter dan pola pikir anak peserta didik. Menurut Piaget (dalam Syah, 2002 : 69-70), pola pemikiran anak dalam masa bermain ada dalam usia Pra-Operasional dan Operasional Konkrit. Usia Pra-Operasional berada pada rentang $2-7$ tahun dengan ciri-ciri kemampuan berbahasa lebih meningkat, berpikir egosentrik, berpikir simbolik, penalaran didominasi oleh persepsi, pemecahan masalah lebih intuitif daripada logis. Sedangkan usia Operasional Konkrit dalam rentangusia 7 - 11 tahun dengan ciri-ciri mampu berkonservasi, logika, penggolongan dan relasi, pengertian akan angka, berkembangnya asas kebalikan dalam berpikir. Oleh sebab itu, dianjurkan dalam masa berpikir dengan karakteristik tersebut, anakanak peserta didik sebaiknya diberikan pola-pola permainan yang sifatnya menstimulasi kemajuan karakteristik berpikir tersebut, dan tidak terlalu dibebankan materimateri pembelajaran yang berkarakteristik berpikir abstrak yang belum lazim pada masanya. Kenyataan yang terjadi dalam masyarakat Bali dewasa ini adalah adanya fenomena bahwa banyak orang tua yang tidak lagi mengajarkan permainan tradisional 


\section{$\frac{M}{3} \frac{1}{11}$ \\ Sang Acharya: Jurnal Profesi Guru \\ Universitas Hindu Negeri I Gusti Bagus Sugriwa \\ Denpasar \\ http://ejournal. uhnsugriwa.ac.id/index.php/ppg \\ Volume. 2, Nomor 1 Mei 2021; e ISSN: 2722-8614}

pada anak-anaknya. Aktivitas bermain sering disepelekan dan disebut-sebut sebagai faktor utama yang menyebabkan kebodohan pada anak karena menyebabkan berkurangnya jam belajar.

Berkurangnya aktivitas bermain pada anak juga disebabkan oleh adanya persepsi yang keliru oleh para orang tua bahwa daripada bermain, sebaiknya waktu-waktu senggang diisi dengan aktivitas belajar seperti kursus atau les mata pelajaran. Sesungguhnya hal ini merupakan pola pembelajaran yang tidak seimbang karena akan berdampak pada munculnya kejenuhan belajar pada anak. Anak diporsir terus menerus hampir sepanjang hari hanya melatih otak kirinya tanpa diimbangi dengan melatih otak kanannya. Menurut Goldman (dalam Erman, 2008 : 5) mengemukakan bahwa struktur otak, sebagai instrumen kecerdasan, terbagi dua menjadi kecerdasan intelektual pada otak kiri dan kecerdasan emosional pada otak kanan. Kecerdasan intelektual mengalir bergerak (flow) antara kebosanan bila tuntutan pemikiran rendah dan kecemasan bila terjadi tuntutan banyak. Kenyataan lain yang turut andil dalam menggusur eksistensi permainan tradisional Bali adalah maraknya permainan-permainan berbasis teknologi, seperti video game, play station, atau game online. Hal ini berdampak pada munculnya sikap individualistis dan anti sosial pada anak. Disamping itu juga turut melunturkan pemahaman anak-anak akan warisan budayanya. Dalam hal ini perlu disadari bahwa permainanpermainan tradisional Bali merupakan sistem pembelajaran yang memiliki kompleksitas aspek yang dilatih, yaitu afektif, kognitif, dan psikomotor. Hal yang tidak kalah pentingnya dalam praktik pemberian pengalaman belajar melalui permainan tradisional Bali, khususnya Penyu Mataluh ini adalah banyaknya penekanan pada konstruksi kecerdasan emosional. Oleh sebab itulah perlu adanya upaya untuk menggali pola-pola serta nilai-nilai pendidikan yang terkandung dalam permainan-permainan tradisional Bali agar dapat dipahami fungsinya sebagai media pembelajaran bagi anak, sehingga dapat diimplementasikan dan eksistensinya dapat dipertahankan secara berkelanjutan.

\section{PEMBAHASAN}

\subsection{Bentuk Permainan Tradisional Bali Penyu Mataluh}

Permainan tradisional Bali Penyu Mataluh (Penyu Bertelur) merupakan permaian yang dimainkan oleh anak-anak di sekitar pesisir pantai pada saat terang bulan, terutama saat bulan purnama. Pada masa lalu, masyarakat pantai yang memiliki profesi sebagai nelayan memburu telur penyu pada saat terang bulan. Penyu suka bertelur di pasir di tepi pantai saat terang bulan. Kisah para nelayan mencari telur penyu kemudian ditransformasikan ke dalam permainan tradisional Penyu Mataluh (Penyu Bertelur).

Permainan tradisional Penyu Mataluh dimainkan oleh anak-anak usia 7 - 10 tahun, yang terdiri dari $4-8$ orang pemain. Seorang pemain berperan sebagai penyu, sedangkan yang lainnya bertugas sebagai nelayan. Pemain penyu bertugas menjaga telur penyu yang berjumlah 10 butir. Telup penyu diperagakan dengan bola pingpong atau pun batu yang bentuknya menyerupai telur. Para pemain nelayan bertugas mengambil atau mencuri telur-telur tersebut. Telur penyu diletakkan di tengah lingkaran yang bergaris tengah $2-3$ meter. Pemain penyu berada pada lingkaran tersebut untuk menjaga telurnya. 


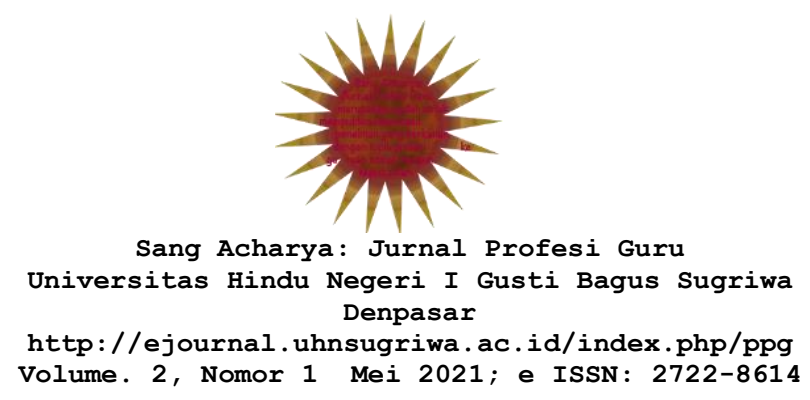

Para nelayan akan datang menyerang hendak mengambil telur, tetapi penyu harus bertahan menjaga keutuhan telurnya. Jika ada pemain nelayan yang dapat disentuh atau pun ditangkap oleh pemain penyu, maka pemain nelayan itu akan menggantikan pemain penyu sebelumnya. Jika pemain penyu tidak mampu menangkap satu pun pemain nelayan hingga telur itu habis diambil pemain nelayan, maka pemain penyu tidak dapat digantikan dan dia harus melanjutkan permainan pada babak berikutnya.

Permainan tradisional Bali Penyu Mataluh biasanya dimainkan dengan iringan lagu "Bulan Makalangan" (Bulan Bersinar Terang). Lagu "Bulan Makalangan" melukiskan gerak-gerik para nelayan mencari telur penyu di bawah sinar rembulan sambil membawa ketupat. Lagu "Bulan Makalangan" dinyanyikan ketika pemain nelayan bergerak menirukan gerakan para nelayan mendayung sampan mengelilingi lingkaran. Setelah syair "be penyu dasa karang" dinyanyikan, serentak para pemain nelayan menyerbbu ke dalam lingkaran untuk mengambil telur. Pemain Penyu pun menjaga telurnya dan berusaha menyerang nelayan yang mencoba masuk ke dalam lingkaran.

\subsection{Permainan Tradisional Bali Penyu Mataluh dan Pelestarian Kearifan Lokal}

Permainan Tradisional Bali Penyu Mataluh berfungsi menanmkan rasa cinta dan kelestarian alam pada diri anak-anak. Konsep filosofi yang melatarbelakangi nilai pelestarian lingkungan dalam permainan tradisional Penyu Mataluh adalah Tri Hita Karana, yakni tiga penyebab atau sumber kesejahteraan bagi umat manusia, yang terdiri atas hubungan harmonis antara manusia dengan Tuhan yang dinamakan Parahyangan, hubungan manusia dengan manusia dengan alam yang disebut Palemahan, hubungan manusia dengan manusis yang disebut dengan Pawongan. Permainan tradisonal Penyu Mataluh merupan bentuk implementasi konsep dan nilai harmonis hubungna manusi dengan alam. Dengan kata lain, permainan ini merupakan cara orang Bali dalam mengapresiakan dan mengadaptasikan diri terhadap alam lingkungan. Bagi masyarkat Bali, alam lingkungan adalah segala sesuatu yang ada di luar diri manusia, seperti bumi, tumbuh-tumbuhan dan hewan. Antara manusia dan lingkungan memiliki hubungan timbal balik, tidak dapat dipisahkan dan sling ketergantungan antara satu dengan yang lainnya. Lingkungan merupakan tempat tinggal dan tempat manusia mendapatkan kesejahteraan dan kebahagiaan. Dengan kesadaran yang dijiwai ajaran agama Hindu, masyarakat Bali memandang hubungan manusia dengan alam lingkungan (bumi) seperti hubungan ibu dengan anak-anaknya yang senantiasa memberikan kesejahteraan. Karena itu, masyarakat Bali menyebut bumi ini sebagai pertiwi. Bumi adalah tempat hidup manusia bersama binatang dan tumbuh-tumbuhan. Karena itu, manusia patut menjaga kelestarian binatang dan tumbuh-tumbuhan.

Dengan permainan tradisional Penyu Mataluh, anak-anak dididik untuk menjaga kelestarian penyu sebagai binatang langka atau satwa yang dilindungi. Anak-anak dilarang mengganggu kelestarian hidup penyu, seperti mengambil atau pun mencuri telur penyu. Nilai adat bersumber agama yang terkandung dalam permainan tradisional Penyu Mataluh perlu direvitalisasi dan ditanamkan pada diri anak-anak sejak dini agar terjadi penguatan karakter bangsa sebagai bangsa yang religius. 


$$
\begin{aligned}
& \text { Sang Acharya: Jurnal Profesi Guru } \\
& \text { Universitas Hindu Negeri I Gusti Bagus Sugriwa } \\
& \text { henpasar } \\
& \text { Volume. 2, Nomor 1 Mei 2021; e ISSN: 2722-8614 }
\end{aligned}
$$

\subsection{Peranan Permainan Tradisional Bali Penyu Mataluh Sebagai Media Pembelajaran dan Pembentukan Karakter}

Belajar adalah suatu proses yang kompleks yang terjadi pada diri setiap orang sepanjang hidupnya. Proses belajar itu terjadi karena adanya interaksi antara seseorang dan lingkungannya. Oleh karena itu, belajar dapat terjadi kapan saja. Salah satu pertanda bahwa seseorang itu belajar adalah adanya perubahan tingkah laku pada diri orang itu yang mungkin disebabkan oleh terjadinya perubahan pada tingkat pengetahuan, ketrampilan, dan sikapnya. Belajar dan pembelajaran merupakan suatu usaha yang dilakukan secara sadar tidak saja dalam upaya untuk menumbuhkembangkan kecerdasan intelegensi, namun juga yang tidak

kalah pentingnya adalah sebagai proses pembentukan karakter (character building). Melalui proses belajar, diharapkan dapat membentuk anak didik yang berkarakter religius, akhlak mulia, beretika dan berbudi pekerti luhur, bermoral, dan berbudaya sesuai budaya yang dimiliki dalam komunitasnya. Dewey (dalam Montolulu, 2005:157) menyatakan bahwa permainan yang bentuknya sederhana dan disukai oleh anak-anak juga orang dewasa ternyata

mengandung suatu nilai yang penting artinya bagi kehidupan bermasyarakat, serta diakui memiliki fungsi yang sangat penting dalam perkembangan jiwa maupun dalam pendidikan. Dinyatakan pula bahwa anak belajar tentang dirinya melalui bermain. Permainan tradisional Penyu Mataluh merupakan bentuk pembelajaran melalui praktekpraktek tindakan yang secara tidak langsung berimplikasi pada pola pembentukan karakter yang dibangun sejak dini. Melalui aktivitas bermain, diharapkan akan tertanam dalam jiwa anak-anak yang

memainkannya untuk dapat memahami bahwa dalam kehidupan dan dalam mencari kebahagiaan tidak bisa dilakukan sendiri tanpa kehadiran orang lain. Dalam hal ini permainan Penyu Mataluh mampu melatih sikap dan kecakapan antar-personal dan intrapersonal pada masing-masing individu anak peserta didik. Kecakapan antar-personal yakni kecakapan untuk memahami dan bekerja dalam kelompok, kemampuan memimpin dan mengorganisir orang lain. Kecakapan ini juga melibatkan emosional, karena dalam mengorganisir orang lain dituntut peka dalam menangkap dan memahami mood, motivasi, dan perasaan-perasaan orang lain, menangani perselisihan antaranggota kelompok. Sedangkan kecakapan intra-personal, yakni kecakapan untuk peka memahami diri sendiri, introspeksi diri (mulat sarira) dalam mengenali kelebihan dan kelemahan diri sendiri dan kemudian mengkoreksinya, serta membentuk disiplin diri bagi dirinya sendiri.

Setiap anak akan mengingat dengan baik para sahabat sepermainannya, sehingga di masadepan, hubungan persahabatan dan solidaritas akan tetap terjalin dengan erat. Dengan adanya kesadaran akan pentingnya solidaritas sosial, maka secara tidak langsung, secara tidak langsung atau dengan sendirinya akan mengurangi potensi-potensi konflik yang dapat terjadi di masyarakat. Dalam hal ini yang dikembangkan adalah jiwa sosial dalam diri anak sehingga nantinya tidak saja menjadi manusia yang terpelajar, namun juga memiliki semangat persatuan yang tinggi. Tak hanya itu, yaitu permainan ini sebagai media pembelajaran yang 


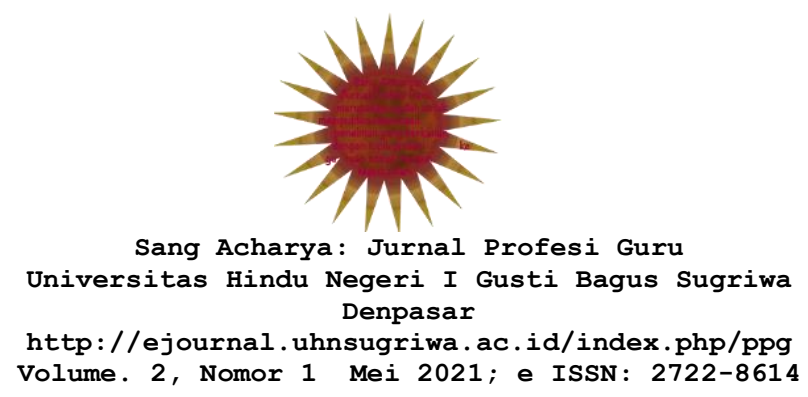

berlandaskan budaya berperan membentuk manusia yang cakap dan berwawasan budaya. Ki Hajar Dewantara (Nuraeni, 2014 : 286) secara tegas menyatakan bahwa kebudayaan tidak dapat dipisahkan dari pendidikan, bahkan kebudayaan merupakan alas atau dasar pendidikan. Tidak ada pendidikan yang tidak dimasuki unsur budaya. Oleh karena itu praktek budaya tidak bisa lepas dari proses pendidikan (Lestawi, 2014 : 86). Dalam praktek tradisi budaya terjadi proses pendidikan, begitu pula pendidikan tidak dapat dilepaskan dari penanaman nilai-nilai budaya. Widja (2009 : 7) menyatakan bahwa melalui proses belajar mengajar atau secara lebih luas proses pendidikan, manusia mampu mengembangkan berbagai potensi atau daya cipta, rasa, karsa, dan karya yang menjadi inti proses budaya. Oleh sebab itu melalui permainan tradisional yang salah satunya adalah permainan Репyи Mataluh berperan sangat penting, tidak saja hanya membelajarkan, namun juga melalui bermain permainan tradisional telah terjadi proses pewarisan budaya. Terlebih di tengah kepungan permainan-permainan yang sifatnya berbasis teknologi yang dapat berimplikasi pada tumbuhnya sifat individualistis dan anti sosial pada anak. Mempertahankan, memelihara, mengembangkan serta menyempurnakan kebudayaan merupakan kewajiban masyarakat baik secara individual, kelompok maupun dalam arti keseluruhan komunitas. Kebudayaan yang secara umum tertuang dalam bentuk kearifan lokal senantiasa mengalami perubahan seiring perkembangan

ilmu pengetahuan dan teknologi, serta derasnya arus komunikasi dan informasi. Dinamika perubahan zaman akan selalu menghasilkan tantangan tersendiri bagi eksistensi suatu kebudayaan. Dengan demikian, anak-anak sebagai generasi penerus tidak saja mewarisi permainan tradisional ini dalam bentuk aktivitas, namun juga mewarisi nilai-nilai pendidikan di dalamnya.

\section{KESIMPULAN}

Nilai-nilai yang terkandung dalam kebudayaan ungat diperlukan dalam usaha mencerdaskan kehidupan bangsa turutama upaya mewujudkan manusia seutuhnya. Permainan tradisional yang berakar dan berkembang di masyarakat perlu dilestarikan dan dikembangkan terus menerus sehingga dapat memperkaya khasana kebudayaan-daerah. Permainan Tradisional Bali Реnyи Mataluh merupakan suatu permainan yang mengutamakan

kebersamaan dan kekompakan serta mengandung nilai-nilai pendidikan yang luhur. Sebagai salah satu hasil budaya masyarakat Bali yang telah diturunkan secara bergenerasi, permainan ini merupakan salah satu media pembelajaran yang menumbuhkan nilai, sikap, kecerdasan, solidaritas sosial, maupun karakter berlandaskan budaya pada anak-anak. Permainan ini akan berimplikasi pada terbentuknya karakter pada masa depan anak yang mencakup terbentuknya jiwa sosial kemasyarakatan berlandaskan solidaritas dan menjadi insan yang berpendidikan dengan berlandaskan budaya. Hal ini semakin terbentuk seiring pertambahan usia dan bertambahnya tingkat kematangan intelektual pada anak. Oleh sebab itu, para orang tua maupun insan-insan pendidikan lainnya hendaknya tidak mengecilkan arti bermain pada anak, karena melalui 


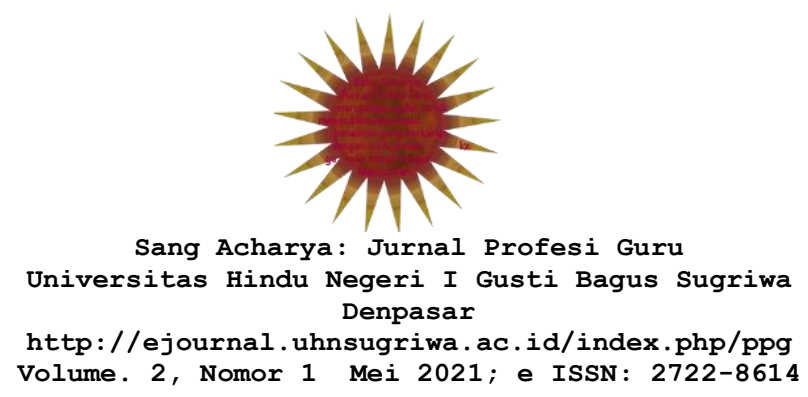

bermain anak dapat mengenal lingkungannya dan menyesuaikan karakternya dengan karakter teman-temannya, sehingga sikap materialistis dan individualistis yang banyak terjadi dewasa ini dapat dihindari sejak dini.

\section{DAFTAR PUSTAKA}

Endraswara, Suwardi. 2009. Metodolgi Penelitian Folklore: Konsep, Teori dan Aplikasi. Yogyakarta: Medpress.

Erman. 2008. "Model Belajar dan Pembelajaran Berorientasi Kompetensi Siswa", dalam Jurnal Pendidikan dan Budaya Educare, Volume 5, No. 2, Pebruari 2008, Fakultas Keguruan dan Ilmu Pendidikan Universitas Langlangbuana Bandung, http://jurnal.fkip.unla.ac.id/inde x.php/educare/article/download/62/62. (diakses 20 Mei 2020).

Lestawi, I Nengah. 2014. "Fungsi Revitalisasi Kearifan Lokal dalam Kehidupan Beragama Bagi Umat Hindu Di Bali" dalam Prosiding Seminar Nasional Filsafat, Agama, dan Tattwa dalam Bingkai Kehidupan Umat Beragama Hindu, tanggal 27-28 Oktober 2014, Fakultas Brahma Widya IHDN Denpasar.

Montolulu, dkk. 2005. Bermain dan Permainan Anak Edisi I. Jakarta: Universitas Terbuka.

Nuraeni, Leni Risna. 2014. "Pendidikan Karakter Berbasis Budaya Lokal Pada Masyarakat

Sunda" dalam Prosiding Seminar Nasional Bahasa dan Budaya dalam Membentuk Karakter Bangsa, 30 September, Program Pascasarjana IHDN Denpasar.

Suarka, I Nyoman. 2011. Nilai Karakter Bangsa Dalam Permainan Tradisional AnakAnak Bali. Denpasar: Udayana University Press.

Sujiono. 2005. Strategi Pembelajaran. Bandung: Falah Production.

Syah, Muhibbin. 2002. Psikologi Pendidikan Dengan Pendekatan Baru. Bandung: Remaja Rosdakarya.

Taro, I Made. 1990. Bunga Rampai Permainan Tradisional Bali. Denpasar: Dinas Pendidikan Dasar Provinsi Bali. 